\title{
Differences in Big Sagebrush (Artemisia tridentata) Plant Stature along Soil-water Gradients: Genetic Components
}

\author{
JERRY R. BARKER AND CYRUS M. MCKELL
}

\begin{abstract}
Genotypic and phenotypic variations are characteristic among big sagebrush (A rtemisia tridentata) plants. One obvious expression is the variability of big sagebrush plant stature along soilwater gradients. Large plants are usually associated with mesic habitats such as drainages or swales, while small plants occupy the xeric portions of the gradients. The purpose of this study was to investigate the genetic influence on big sagebrush plant stature along soil-water gradients. Leaf morphological, phenological, chromatographical, and cytological investigations evaluated potential genetic differences and examined possible subspecies status of the large and small plants. The results of these studies revealed a genetic difference between the large and small plants and confirmed subspecies status. The large plants were identified as basin big sagebrush ( $A$. tridentata spp. tridentata) while the small plants were Wyoming big sagebrush (A. tridentate spp. wyomingensis). Three additional studies examined possible differences in growth potential between the subspecies. A greenhouse and uniform garden study compared seedling and juvenile plant growth. Annual leader growth of mature plants was measured in native populations. Basin big sagebrush plants outgrew Wyoming big sagebrush in the greenhouse, uniform garden, and leader growth experiments. Difference in growth potential between the subspecies may be a consequence of ploidy differences.
\end{abstract}

The most common, important, and widely distributed woody sagebrush (Artemisia L. subgenus tridentatae (Rydb.) E.D. McArthur) is big sagebrush (Artemisia tridentata Nutt.). Big sagebrush is common on millions of hectares throughout western North America from southern Canada to northern Mexico (Beetle 1960, McArthur et al. 1981). This shrub has a wide range of adaptability and grows in various soil types and is associated with numerous plant species from low elevation valleys and plains to high mountain slopes and ridges (Morris et al. 1976, Winward and Tisdale 1977, Winward, 1980). Big sagebrush provides browse and habitat for an array of wildlife and livestock, minimizes soil erosion, and is of value in mined-land reclamation.

Big sagebrush, as do other plant species, adapts to diverse environments through a combination of phenotypic plasticity and genotypic variation. As Caldwell (1979) theorized, the phenotypic diversity of plants is remarkable, but it is not sufficient to accommodate extensive environmental conditions that are found in the range of a widely distributed species such as big sagebrush. Presently, the big sagebrush complex consists of 4 subspecies (Beetle 1960, Beetle and Young 1965, Goodrich et al. in press, McArthur 1983) which are: basin big sagebrush (A. tridentata Nutt. ssp. tridentata), Wyoming big sagebrush (A. tridentata Nutt. ssp. wyomingensis Beetle and Young), mountain big sagebrush ( $A$. tridentata Nutt. ssp. vaseyana (Rydb.) Beetle), and subalpine sagebrush ( $A$. tridentata Nutt. ssp speciformis (Osterhout) Goodrich and McArthur).

\footnotetext{
Authors are former graduate research assistant and professor, respectively, Department of Range Science, Utah State University, Logan. Authors are presently, lecturer, Department of Botany and Range Management, Somali National University, Mogadishu, Somalia and Vice-President for Research, NPI, 417 Wakara Way, Salt Lake City, Utah 84108.

Research was supported by the U.S. Department of Energy and Ecology Center and Department of Range Science, Utah State University. We thank E.D. McArthur for technical assistance, use of laboratory equipment, and review of a draft manuscript.

Manuscript accepted 3 July 1985.
}

Genotypic and phenotypic variation is characteristic of big sagebrush (Beetle 1960, Hanks et al. 1973, McArthur et al. 1981, West et al. 1978). An obvious expression is the variability in big sagebrush plant stature along soil-water gradients (Beetle 1960, Hall and Clements 1923, Hanks et al. 1973). Large plants may reach a height of 3.5 to $5.0 \mathrm{~m}$ in mesic habitats such as drainages or swales, while plants less than $1.0 \mathrm{~m}$ tall are associated with the xeric portions of moisture gradients.

Considering the differences in big sagebrush plant stature, a logical question arises: Are the differences in plant stature due to genetic or environmental influences? The research herein discusses the influence of genetics on big sagebrush plant stature. Edaphic differences associated with the large and small big sagebrush plants are reported elsewhere (Barker 1981, Barker and McKell 1983).

\section{Study Sites}

Three sites were selected for study because of differences in plant stature that were observed within relatively short distances (Barker and McKell 1983). At each site, plant height decreased with distance along a transect at a right angle to a drainage. Plant height along the drainages averaged $2.5 \mathrm{~m}$ and decreased to less than 1.0 $\mathrm{m}$. The distance of the plant height gradient transects were 60,40 , and $100 \mathrm{~m}$ for Sage Creek, Greasewood Wash, and Maeser, respectively.

The Sage Creek study site is located $4.8 \mathrm{~km}$ west of Sage Creek Junction on Highway 30 in Rich County, Utah. Average annual precipitation ranges from 25 to $30 \mathrm{~cm}$. The frost-free period is from 55 to 65 days (personal communication, Soil Conservation Service, Logan, Utah). The site has an elevation of $1,950 \mathrm{~m}$, northern exposure, and slope variation of 2 to $5 \%$. Soils associated with the large and small plants are respectively, Xeric Torrifluvent and Typic Haplargid.

The Greasewood Wash study site is located $10.2 \mathrm{~km}$ north of the Jim Bridger Coal Mine along Sweetwater County Road 4-17 in southern Wyoming. Average annual precipitation varies from 12 to $22 \mathrm{~cm}$. The frost-free period ranges from 80 to 110 days (personal communication, Soil Conservation Service, Rock Springs, Wyoming). The site has an elevation of $2,063 \mathrm{~m}$, western exposure and slope of about $3 \%$. The soils associated with the large and small plants are respectively, Xerollic Torrifluvent and Typic Camborthid.

The Maeser study site is located in the Uinta Basin, $11.2 \mathrm{~km}$ north of Maeser, Utah along Taylor Mountain Road. Average annual precipitation is 25 to $30 \mathrm{~cm}$. The frost free period ranges from 110 to 140 days (personal communication, Soil Conservation Service, Vernal, Utah). The site has an elevation of $2,296 \mathrm{~m}$, southern exposure, and slope of $3 \%$. The soil associated with the large and small plants is an Ustic Torrifluvent.

\section{Methods and Materials}

To evaluate genetic differences and verify possible subspecific status between the large and small big sagebrush plants, leaf morphological, phenological, chromatographical, and cytological investigations were conducted. Three additional studies examined potential differences in growth rates between the large and small statured plants. Greenhouse and uniform garden experiments compared seedling and juvenile plant growth, respectively. Also, annual 
leader growth of mature plants was measured at each study site.

\section{Leaf Morphology}

Leaf length, leaf width, and leaf length/width ratios were compared to evaluate morphological differences between the large and small plants at each study site. Twenty plants per size class per study site were randomly selected. Leaves for measurement were randomly selected from the top portions of the plants. Data were statistically compared using analysis of variance and Duncan's new multiple range test (Ott 1977).

\section{Phenology}

To compare the phenological progression during the 1980 growing season, 10 plants per size class per site were randomly selected. The methods described by West and Wein (1971) for phenological plant comparisons were followed. The phenological index used was modified from DePuit and Caldwell (1973). Phenological observations were conducted every 2 weeks starting in May 1980. To reduce variability, the southwest portion of each plant was marked and used for determining phenological development. Data were compared using analysis of variance and Duncan's new multiple range test (Ott 1977).

\section{Chromatography}

A portion of annual growth was harvested from 20 plants equally spaced along a transect ( 3 transects per site). Plant materials were collected on 23 and 24 September 1980 at Greasewood Wash and Maeser and 1 October 1980 at Sage Creek. A total of 60 plants per study site were analyzed. Two-dimensional, ascending, paper chromatography as described by Hanks et al. (1973) was followed. The unweighted paired group method using arithmetic averages (UPGMA) cluster analysis with the Jaccard primary resemblance coefficient grouped the chromatograms into meaningful results (Sokal and Sneath 1973).

\section{Cytology}

Mitotic chromosome analyses were made for 5 plants per size class at each site to ascertain if ploidy differences existed using methods described by McArthur et al. (1981). Plants were randomly selected from the ends of each gradient. Mitotic spreads were prepared by squashing root tips of 2- to 3-day old seedlings. To avoid the problem of endoploidy, somatic chromosomes were counted in 3 root tips per parent plant and 3 to 4 cells per root tip. A Zeiss $R A$ research microscope with $100 \times$ oil immersion and phase contrast was used to observe the chromosomes.

\section{Greenhouse Study}

The objective of this study was to compare seedling growth under 3 soil-water regimes. Seeds were collected 3 and 4 November from each study site. At the same time, the surface top $15 \mathrm{~cm}$ of soil was collected to serve as the plant growth medium.

In the greenhouse, the amount of water at field capacity (F.C.), field capacity minus $5 \%$ water content (F.C. $-5 \%$ ), and field capacity minus $10 \%$ water content (F.C. $-10 \%$ ) was estimated for each of the 6 soils.

Plastic lined, $973 \mathrm{ml}$ ( 1 quart), paper milk cartons were used as plant containers. One kilogram of air-dried soil was placed in each container. Enough water was then added to bring the soil to F.C., F.C. $-5 \%$, or F.C. $-10 \%$. A plastic bag was placed over the containers to reduce evaporation. Seeds were sown on 26 January 1980. The plastic bags were maintained over the containers until the seedlings were about $1.0 \mathrm{~cm}$ tall. Then, the plastic bags were cut and laid directly on the soil with a small hole to allow seedling growth. At this time, seedlings were thinned to one per container.

To maintain the proper water content, containers were weighed every 2 to 3 days and then brought up to weight with water. Seedling height was measured every 2 weeks until harvest. Sccdlings were then oven-dried at $80^{\circ} \mathrm{C}$ for $24 \mathrm{~h}$ and weighed. Data were compared using analysis of variance and Duncan's new multiple range test (Ott 1977).

\section{Uniform Garden Study}

The uniform garden experiment compared growth of juvenile plants associated with each size class per site. The garden was in the Green Canyon Research Area of the Ecology Center, Utah State University, located northeast of Logan, Utah.

Seeds were collected on 3 and 4 November 1979 from 10 randomly selected plants per size class per study site. Seeds were germinated in plastic trays and then 12 seedlings per parent plant per size class per site were planted into containers on 4 February 1980. The growth medium was peat moss, vermiculite, and native soil (2:2:1 by volume). On 5 May 1980 , seedlings were placed out-of-doors for hardening. Six seedlings per parent plant were transplanted on 5 June 1980. A completely randomized field-plot design was used. Plant height was measured 7 November 1980. Data were analyzed using analysis of variance and Duncan's new multiple range test (Ott 1977).

\section{Leader Length}

Leader length was used to assess the annual growth of mature plants at each site. Twenty plants per size class per site were randomly selected to be measured in the fall, 1980. The five-longest stems growing on the top portion of a plant were measured. Data were statistically compared by analysis of variance and Duncan's new multiple range test (Ott 1977).

\section{Results}

The morphological, phenological, chromatographical, and cytological investigations confirmed that the large and small plants were, respectively, basin big sagebrush and Wyoming big sagebrush. Hereafter, the large and small plants will be referred to as basin big sagebrush and Wyoming big sagebrush, respectively.

\section{Leaf Morphology}

Leaf-length/width ratios were significantly different $(P<0.05)$ between basin and Wyoming big sagebrush plants (Table 1). Basin

\section{Table 1. Leaf morphological comparisons between ssp. tridentata and wyomingensis.}

\begin{tabular}{lcc}
\hline \hline Characteristic & Tridentata & Wyomingensis \\
\hline Leaf length $(\mathrm{mm})$ & $12.7 \mathrm{a}^{1}$ & $10.3 \mathrm{a}$ \\
Leaf width $(\mathrm{mm})$ & $2.9 \mathrm{a}$ & $3.0 \mathrm{a}$ \\
Leaf length $/$ width & $4.6 \mathrm{a}$ & $3.5 \mathrm{~b}$ \\
\hline
\end{tabular}

'Each mean is the average of 60 plants. Those means that are followed by the same letter for each characteristic are not significantly different $(P>0.05)$.

big sagebrush had larger ratios than Wyoming big sagebrush. Leaf length and width were statistically similar for the subspecies. The site, subspecies interaction was not significant $(P<0.05)$.

\section{Phenology}

Phenological progression for the 2 subspecies was similar with the exception of flower initiation and seed development (Fig. 1). On 15 April, leaf buds were beginning to swell. From 13 May to 8 July, vegetal growth was rapid, but by $25 \mathrm{July,} \mathrm{vegetal} \mathrm{growth} \mathrm{was}$ reduced. However, reproductive shoot and flower bud growth was underway. By 5 September, both basin and Wyoming big sagebrush plants were flowering. Seed development was underway on 23 September. Differences in phenological development were found on 10 August, 5 September, and 23 September with Wyoming big sagebrush being significantly more advanced $(p<0.05)$ than basin big sagebrush.

\section{Chromatography}

Chromatographic differences were found between the subspecies (Table 2). All spots were common to both subspecies except number 3, which did not occur on chromatograms of basin big sagebrush. Spots numbered 1, 5, 35, 37, and 38 were light colored on basin big sagebrush chromatograms and intensely colored on 


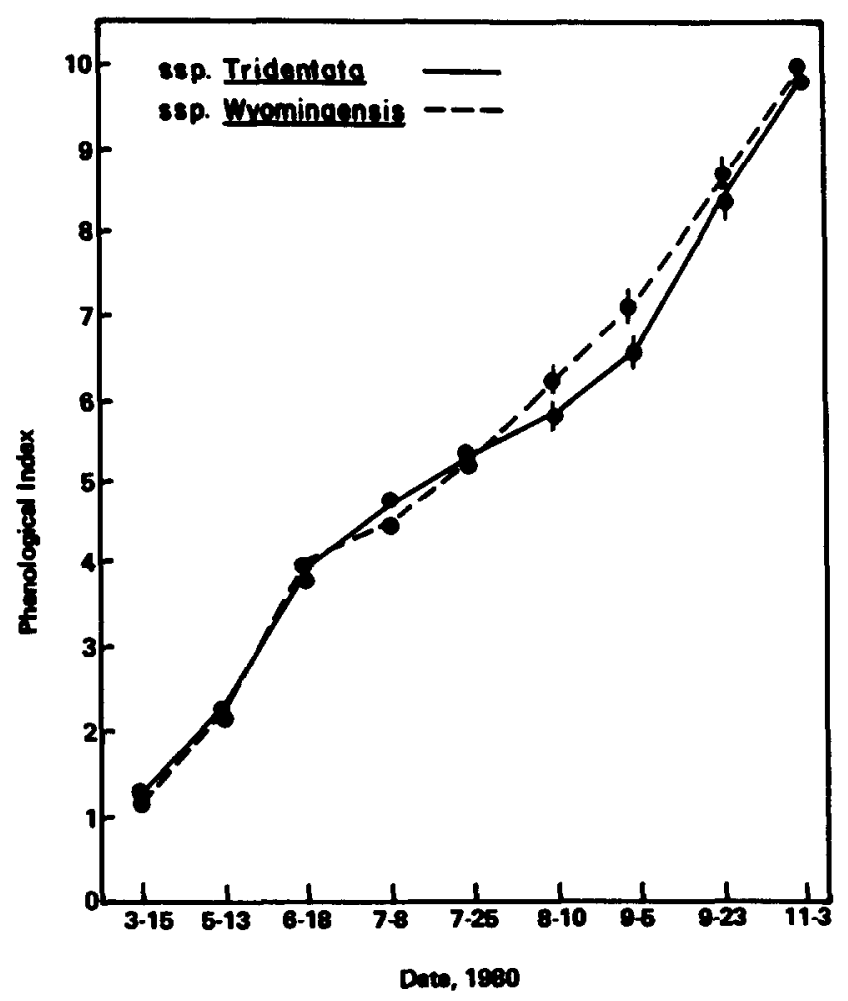

Fis. 1. Phenological development of ssp. tridentata and wyomingensis plant populations during 1980. Data points are the average of 30 plants with confidence intervals formed at the. $95 \%$ level. The phenological index is as follows: $0=$ winter dormancy; $1=$ leaf bud swell; $2=$ leaf emergence; 3 = vegetal growth; $4=$ floral shoot growth; 5 flower bud swell; $6=$ flowering begins; $7=$ flowering; $8=$ seed development; $9=$ dispersion; $10=$ senescence.

Table 2. Chromatographic spot frequencies, colors, and color intensities for ssp. tridentate and wyomingensis.

\begin{tabular}{|c|c|c|c|c|c|c|}
\hline \multicolumn{3}{|c|}{ Spot color' } & \multicolumn{2}{|c|}{ Color intensity ${ }^{2}$} & \multicolumn{2}{|c|}{ Spot frequency } \\
\hline Spot & UV & $\mathbf{U V + N H 3}$ & $\begin{array}{c}\text { Triden } \\
\text { tata }\end{array}$ & $\begin{array}{c}\text { Wyoming- } \\
\text { ensis }\end{array}$ & $\begin{array}{c}\text { Triden- } \\
\text { tata }\end{array}$ & $\begin{array}{c}\text { Wyoming - } \\
\text { ensis }\end{array}$ \\
\hline 1 & yo & yo & 1 & 3 & 0.89 & 1.00 \\
\hline 3 & yo & yo & - & 1 & 0 & 0.26 \\
\hline 5 & yo & yo & 1 & 3 & 0.93 & 1.00 \\
\hline 7 & $\mathbf{y}$ & $\mathbf{y}$ & 1 & 1 & 0.27 & 0.26 \\
\hline 10 & $\mathbf{v}$ & vb & 2 & 2 & 0.96 & 0.98 \\
\hline 15 & $d v$ & dvb & 3 & 3 & 1.00 & 1.00 \\
\hline 20 & lb & Ib & 1 & 1 & 0.22 & 0.12 \\
\hline 25 & lb & yg & 1 & 1 & 0.68 & 0.60 \\
\hline 30 & bv & bv & $i$ & 1 & 0.57 & 0.70 \\
\hline 33 & - & $\mathbf{v}$ & 1 & 1 & 0.07 & 0.12 \\
\hline 35 & $\mathbf{b b}$ & $\mathbf{b b}$ & 1 & 3 & 0.68 & 0.88 \\
\hline 37 & - & 0 & 1 & 3 & 0.21 & 0.46 \\
\hline 38 & - & $\mathbf{v}$ & 1 & 3 & 0.49 & 0.75 \\
\hline 39 & - & $v$ & 1 & 1 & 0.67 & 0.64 \\
\hline 40 & $\mathbf{b}$ & $y$ & 2 & 3 & 1.00 & 1.00 \\
\hline 45 & bv & bv & 1 & 1 & 0.02 & 0.09 \\
\hline 47 & - & $\mathbf{v}$ & 1 & 1 & 0.44 & 0.43 \\
\hline 50 & $\mathbf{p}$ & yp & 1 & 1 & 0.02 & 0.09 \\
\hline 55 & $d v$ & vb & 3 & 3 & 1.00 & 0.98 \\
\hline 58 & $\mathbf{d b}$ & yg & 1 & 1 & 0.21 & 0.23 \\
\hline 65 & b & yg & 2 & 2 & 1.00 & 1.00 \\
\hline 70 & lb & yg & 1 & 1 & 0.07 & 0.02 \\
\hline 75 & $\mathbf{v}$ & $\mathrm{vb}$ & 1 & 1 & 0.92 & 0.88 \\
\hline 80 & - & bg & 1 & 1 & 0.77 & 0.79 \\
\hline
\end{tabular}

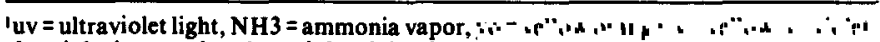
$v b=$ violet brown, $d v=$ deep violet, $d v b=$ deep: , e l,

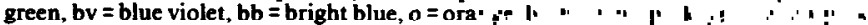
$\mathrm{db}=$ dark blue, $\mathrm{bg}=$ blue green.

$2 \mathrm{l}=$ light, $2=$ average, $3=$ intense
Wyoming big sagebrush chromatograms.

Cluster anslysis used chromatogram spot frequencies to separate the subspecies for each study site. Basin and Wyoming big sagebrush were found to be about 60,50 , and $55 \%$ similar at Sage Creek, Greasewood Wash, and Maeser, respectively.

\section{Cytology}

At each study site basin big sagebrush plants were diploid $(2 n=18)$ and Wyoming big sagebrush plants were tetraploid $(2 n=36)$. One triploid $(2 n=27)$ seedling was identified from the Maeser study site, indicating some hybridization.

\section{Greenhouse Study}

Under uniform growing conditions basin big sagebrush seedlings grew taller than Wyoming big sagebrush seedling (Fig. 2). During the first 9 weeks, growth was the same for both subspecies. After that time, basin big sagebrush seedlings grew significantly $(P<0.05)$ taller than Wyoming big sagebrush.

Seedlings responded differently to the 3 water treatments (Fig. 2). Seedling growth at F.C. was the tallest while at F.C. $-10 \%$ seedling growth was the shortest. The subspecies, water treatment interaction for seedling height was not significantly different $(P>0.05)$.

Seedling shoot biomass varied significantly $(p<0.05)$ between subspecies and among water treatments. Basin big sagebrush and Wyoming big sagebrush mean seedling shoot production was 1.3 and $1.0 \mathrm{~g}$, respectively. Seedlings grown at F.C. produced the most biomass while seedlings at F.C.-10\% produced the least. Seedling biomass production at F.C., F.C. $-5 \%$, and F.C. $-10 \%$ was respectively $1.9,1.1$, and $0.4 \mathrm{~g}$. The subspecies, water treatment interaction for shoot biomass was not significantly different $(P>0.05)$.

\section{Uniform Garden}

Juvenile plants showed differential growth in the uniform garden. Overall basin big sagebrush plants were significantly $(P<0.05)$ taller than Wyoming big sagebrush plants; average height was 22.8 and $18.0 \mathrm{~cm}$, respectively. There was also a significant difference $(P<0.05)$ in the subspecies, site interaction (Table 3). Basin big sagebrush plants were taller than Wyoming big sage-

Table 3. Mean seedling beight after one growing season in a uniform garden. Parent plants of the seedlings are located at the Sage Creek, Greasewood Wash, and Maeser Study aites.

\begin{tabular}{lc}
\hline Site subspecies & Height $(\mathrm{cm})$ \\
\hline Sage Creek & \\
$\quad$ Tridentata & $24.1 \mathrm{a}^{\mathrm{1}}$ \\
$\quad$ Wyomingensis & $18.9 \mathrm{bc}$ \\
Greasewood Wash & \\
$\quad$ Tridentata & $18.3 \mathrm{bc}$ \\
$\quad$ Wyomingensis & $15.4 \mathrm{c}$ \\
Maeser & \\
$\quad$ Tridentata & $26.0 \mathrm{a}$ \\
Wyomingensis & $19.7 \mathrm{~b}$ \\
\hline
\end{tabular}

'Each mean is the average of at least 40 plants. Means followed by the same letter are not significantly different $(P>0.05)$.

brush plants from Greasewood Wash were taller but not significantly $(P>0.05)$ so, than Wyoming big sagebrush plants from that location.

\section{Leader Length}

Annual leader growth of mature plants was significantly different $(P<0.05)$. Subspecies leader length for basin and Wyoming big sagebrush plants was 14.5 and $8.5 \mathrm{~cm}$, respectively. The subspecies, site interaction was not significant $(P>0.05)$. 


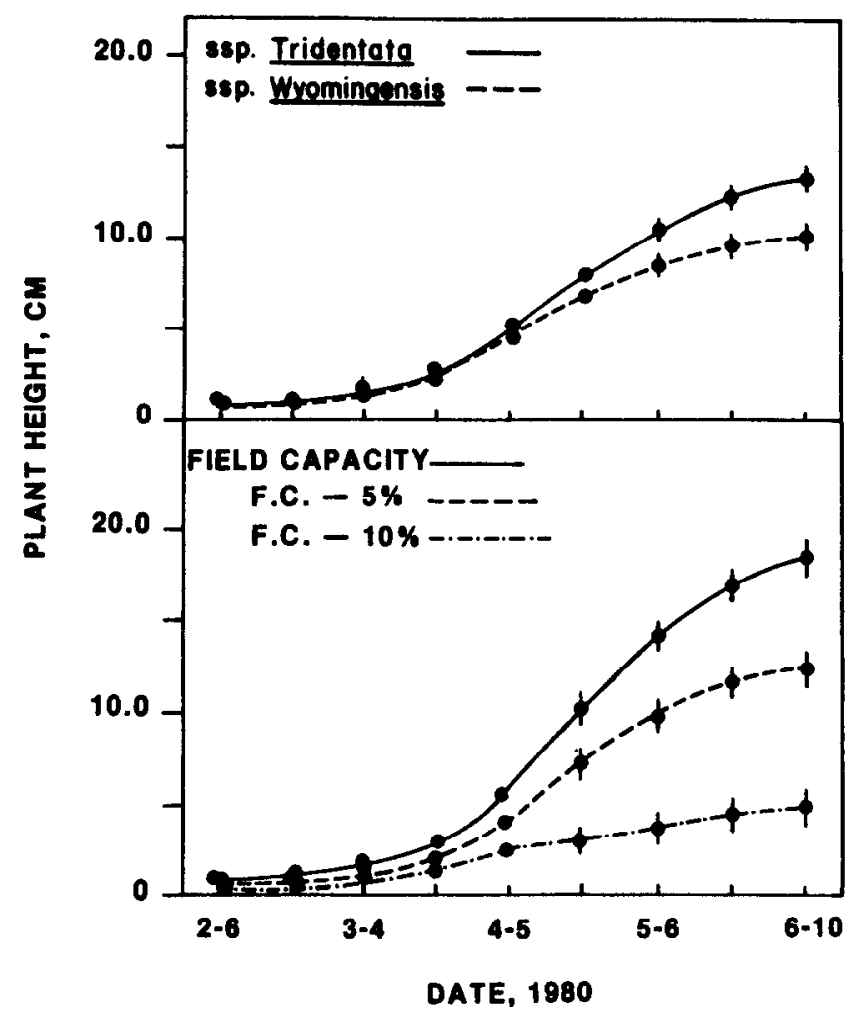

Fig. 2. Growth of ssp. tridentata and wyomingensis (Top). Seedling growth on soil at field capacity, field capacity minus 5 and $10 \%$ water content (bottom). Data points are the average of 144 (top) and 96 (bottom) seedlings with confidence levels formed at the $95 \%$ level.

\section{Discussion}

The leaf morphological, phenological, cytological, and chromatographical studies indicate genetic differences between the large and small plants along the soil water gradients and confirm subspecies status (McArthur et al. 1979, Winward 1980). Basin big sagebrush occurs mainly in the mesic habitats while Wyoming big sagebrush is restricted to the xeric habitats along the soil-water gradients (Barker and McKell 1983).

Leaf morphological features are one criterion used to separate the subspecies (Beetle and Young 1965, McArthur et al. 1979, Winward 1980). In the present study, differences in the leaf length/width ratios were found. This supports the research of the beforementioned scientists.

Subtle differences were found in the phenological development between the 2 subspecies. Wyoming big sagebrush plants flowered earlier than basin big sagebrush. Winward and Tisdale (1977) reported no consistent differences in phenological development between basin and Wyoming big sagebrush plants in Idaho. However, Winward (1970) reported that Wyoming big sagebrush plants matured earlier when growing on extreme xeric sites. Perhaps the arid soil conditions associated with Wyoming big sagebrush at the current study sites induced early flower and seed set (Barker and McKell 1983).

As pointed out by various researchers, morphological differences among big sagebrush subspecies are subtle and variable (Beetle and Young 1965, West et al. 1978, Winward 1980). Thus chromatography has been suggested to be a helpful tool in separating the subspecies (Hanks et al. 1973, West et al. 1978). Two-dimensional, paper chromatography consistently separated the 2 subspecies at each of the current study sites.

The chromatographic study also was of value in elucidating the relationship of the subspecies along the soil water gradients. At each study site basin big sagebrush plants occurred in the mesic habitats while Wyoming big sagebrush plants occurred in the xeric habitats (Barker 1981, Barker and McKell 1983). Apparently, soil-water is the driving force that partitions the subspecies along the gradients. Wyoming big sagebrush in wildland situations usually occupies the more xeric soils than basin big sagebrush when the 2 subspecies are associated together (Barker and McKell 1983, Morris et al. 1976, Winward and Tisdale 1977). Other researchers have shown the effectiveness in soil water as a force in segregating plant genotypes (e.g. Brown et al. 1974, Freeman et al. 1976, Hamrick and Allard 1972).

Polyploidy confirms that genetic differences exist in big sagebrush plants along the soil water gradients. Winward and Tisdale (1977) found that Wyoming big sagebrush plants are tetraploid and that basin big plants are both diploid and tetraploid. McArthur et al. (1981) in an extensive chromosomal study of the woody sagebrushes reported Wyoming big sagebrush to be essentially tetraploid with occasional hexaploid plants. They also found diploid and tetraploid basin big sagebrush plants, but the diploid condition was the most common.

An interesting note is the relationship of ploidy level to soil moisture condition found in the current study. The diploid plants, basin big sagebrush, occurred in the mesic portion of the gradients. The tetraploid plants, Wyoming big sagebrush, occurred in the xeric portion of the gradients. There is evidence that polyploidy within a big sagebrush subspecies may increase with aridity (.E.D McArthur, personal communication). Furthermore, both creosotebush (Larrea divaricata) (Barbour 1969) and fourwing saltbush (Atriplex canescens) (H.C. Stutz, personal communication; Stutz et al. 1975) seem to show an increase in polyploidy with aridity. Perhaps polyploidy endows shrubs with the ability to withstand increased aridity.

The differences in growth potential between the subspecies may also be a result of polyploidy. In the greenhouse, uniform garden, and leader growth studies, basin big sagebrush outgrew Wyoming big sagebrush. However, Harniss and McDonough (1975) reported no differences in seedling growth between these subspecies during a 10-week period. Growth differences between basin and Wyoming big sagebrush in a multi-year uniform garden study were reported by McArthur and Welch (1982). They found that plant height, crown, cover, production, and annual leader growth for basin big sagebrush were greater than for Wyoming big sagebrush. They also showed that the faster growing basin big sagebrush plants were diploid while the slower growing plants were tetraploid. Furthermore, creosote bush (Barbour 1969), fourwing saltbush (Stutz et al. 1975), and shadscale (Atriplex confertifolia) (Stutz and Sanderson 1983) also seem to show a decrease in growth potential with an increase in ploidy level.

\section{Summary and Conclusions}

Leaf morphological, phenological, chromatographical, cytological, and growth studies evaluated genetic and growth potential differences between large and small statured big sagebrush plants growing along soil-water gradients. The large and small plants were identified as basin and Wyoming big sagebrush, respectively. Basin and Wyoming big sagebrush plants were located respectively in the mesic and xeric portions of the gradients. Basin big sagebrush has a greater growth potential than Wyoming big sagebrush as indicated by the growth studies. The differential growth between the subspecies may result from polyploidy. Difference in growth potential and habitat selection between the subspecies should be considered in planning for range improvement, wildlife habitat enhancement, and plant breeding programs.

\section{Litergture Cited}

Barbour, M.D. 1969. Patterns of genetic similarity between Larrea divaricata of North and South America. Amer. Mid. Nat. 81:55-57.

Barker, J.F. 1981. Genetic differences between large and small Artemisia tridentata plants in contiguous populations. Ph.D. Dissertation, Utah State Univ., Logan. 
Barker, J.R., and C.M. McKell. 1983. Habitat differences between basin and Wyoming big sagebrush in contiguous populations. J. Range Manage. $36: 450-454$.

Beetle, A.A. 1960 . A study of sagebrush, the section Tridentatae of Artemisia. Univ. Wyoming Exp. Sta. Bull. No. 638.

Beetle, A.A., and A. Young. 1965. A third subspecies in the Artemisia tridentata complex. Rhodora 67:405-406.

Brown, A.H.D., D.R. Marshall, and L. Albrecht. 1974. The maintenance of alcohol dehydrogenase polymorphism in Bromus mollis L. Aust. J. Biol. Sci. 27:245-259.

Caldwell, M.M. 1979. Physiology of sagebrush. p. 74-85. In: The Sagebrush Ecosystem. A Symposium. Utah State Univ., College of Natural Resources, Logan.

DePuit, E.J., and M.M. Caldwell. 1973. Seasonal pattern of net photosynthesis of Artemisia tridentata. Amer. J. Bot. 60:425-435.

Freeman, D.C., L.G. Klokoff, and K.T. Harper. 1976. Differential resource utilization by the sexes of dioecious plants. Science 193:597-599.

Goodrich, S., E.D. McArthur, and A.H. Winwood (in press). A new combination (ssp. speciformis) and a new variety in Artemisia tridentata. Great Basin Naturalist.

Hall, H.M., and F.E. Clements. 1923. The phylogenetic method in taxonomy. The North American species of Artemisia, Chrysothamnus, and Atriplex. Carnegie Inst., Wash. Pub. No. 326.

Hamrick, J.C., and R.W. Allard. 1972. Microgeographical variation in allozyme frequencies in Avena barbata. Proc. Nat. Acad. Sci. USA 69:2100-2104.

Hanks, D.L., E.D. McArthur, R. Stevens and A.P. Plummer. 1973. Chromatographic characteristics and phylogenetic relationship of Artemisia, section Tridentatae. USDA Forest Serv. Res. Paper INT-141.

Harniss, R.A., and W.T. McDonough. 1975. Seedling growth of three big sagebrush subspecies under controlled temperature regimes. J. Range Manage. 28:243-244.

McArthur, E.D. 1983. Taxonomy, origin and distribution of big sagebrush (Artemisia tridentata) and allies (subgenus Tridentata). p. 3-12. In: K.L. Johnson (ed.). Proceedings of the First Utah Shrub Ecology Workshop. College of Natural Resources, Utah State Univ., Logan.
McArthur, E.D., A.C. Blauer, A.P. Plummer, and R. Stevens. 1979. Characteristics and hybridization of important Intermountain shrubs III. Sunflower family. USDA For. Serv. Res. Paper INT-220.

McArthur, E.D., C.L. Pope, and D.C. Freeman. 1981. Chromosomal studies of subgenus Tridentatae or Artemisia: Evidence for autopolyploidy. Amer. J. Bot. 68:589-605.

McArthur, E.D., and B.L. Welch. 1982. Growth rate differences among big sagebrush (Artemisia tridentata) accessions and subspecies. J. Range Manage. 36:396-401.

Morris, M.S., R.G. Kelsey, and D. Griggs. 1976. The geographic and ecological distribution of big sagebrush and other woody Artemisia in Montana. Proc. Montana Acad. Sci. 36:56-79.

Ott, L. 1977. An introduction to statistical methods and data analysis. Duxbury Press, North Scituate, Mass.

Sokal, R.R., and P.H.A. Sneath. 1973. Numerical taxonomy: The principles and practice of numerical classification. W.H. Freeman, San Francisco.

Stutz, H.C., J.M. Melby, and G.K. Livingston. 1975. Evolutionary studies of Atriplex: A gigas diploid population of Atriplex canescens. Amer. J. Bot. 62:236-245.

Stutz, H.C., and S.C. Sanderson. 1983. Evolutionary studies of Atriplex. Chromosome races of $A$. confertifolia (Shadscale). Amer. J. Bot. 70:1536-1547.

West, N.E., and R.W. Wein. 1971. A plant phenological index technique. Bioscience 21:116-117.

West, N.E., R.T. Tausch, K.H. Rea, and P.T. Tueller. 1978. Taxonomic determination, distribution, and ecological indicat or values of sagebrush within the pinyon-juniper woodlands of the Great Basin. J. Range Manage. 21:87-92.

Winward, A.H. 1970. Taxonomic and ecological relationships of the big sagebrush complex in Idaho. Ph.D. Diss., Univ. of Idaho, Moscow.

Winward, A.H. 1980. Taxonomy and ecology of sagebrush in Oregon. Oregon State Univ. Agr. Exp. Sta. Bull. 642, Corvallis.

Winward, A.H., and E.W. Tisdale. 1977. Taxonomy of the Artemisia tridentata complex in Idaho. Univ. of Idaho, Forest, Wildlife, and Range Exp. Sta. Bull. No. 19, Moscow.

\section{DEADLINE DATES}

Items such as columns, advertisements, announcements, lists, and reports must be in the Denver office by the following dates to ensure publication in the respective issues of RANGELANDS:

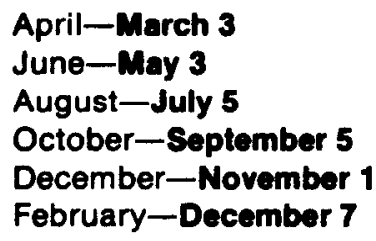

Position announcements must be in the Denver office by the following dates to be published in the respective issues of the JOURNAL OF RANGE MANAGEMENT:

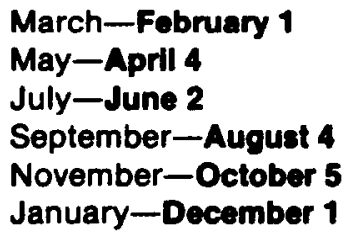

